\title{
Religious Rights, Noise Pollution and the Nigerian Constitution: A Conflict
}

\author{
Ifeoluwa Etomilade-Oduola* Damilola Odunayo Sawyerr \\ Research Fellow, Department of International Law, Nigeria Institute of Advanced Legal Studies, Lagos, Nigeria
}

\begin{abstract}
The paper discusses freedom of thought, conscience and religion with regard to the National Environmental Standards and Regulations Enforcement Agency(NESREA) which regulates noise including those emanating from religious buildings and argues that the inclusion of sounds emanating from religious buildings and produced when manifesting a religious belief in the category of sounds to be regulated would not only limit the right but would also negatively affect other rights connected to this religious right as stated in Section 38, especially as these rights are intertwined. A critical appraisal of section 45(1) of the 1999 Amended Nigeria Constitution which influenced the enactment of NESREA showed that the restriction has not been sufficiently justified in the absence of adequate proof of the adverse effect of noise pollution to Nigerians. Based on this analysis the paper identified a conflict of laws particularly between the rights stated in Sections 37-41 on one hand and Section 45 and NESREA on the other hand considering the fact that the Constitution bestows the rights in Part IV and thereafter restricts the way such rights should be manifested.
\end{abstract}

Keywords: Noise Pollution, Religious Freedom, Constitution, Conflict of laws, Nigeria

DOI: $10.7176 / \mathrm{JLPG} / 102-05$

Publication date:October $31^{\text {st }} 2020$

\section{Introduction}

Without doubt sound is an integral part of being human and it is fundamental to having a meaningful life. In fact, sound itself is life, which in essence means it cannot be removed from our daily activities as humans. Being a moral creature with empathy and faith, human beings are generally predisposed to believing in something higher than them. That need to 'believe in something' freely without fear, eventually informed the enactment of various human rights instruments over the years which recognized various rights including people's freedom of religion that encompasses manifesting and propagating such belief in worship, teaching, practice and observance.

Worship which involves unencumbered sounds or melodious tunes is an integral part of manifesting a religious belief particularly for those of the Christian faith. It should be noted that changes around the world, has caused acceptable norms and practices to be relegated, restricted or out rightly removed to reflect the modern day desire for solitude. Part of such changes is the modern desire for privacy, solitary life and a move away from religion. This shift inevitably influenced the restriction imposed on sounds, considered to be unacceptable or above the level deemed appropriate. This ceiling on sound has undeniably suppressed the manifestation of people's religious freedom.

Aside the influence of modernity, religious pluralism and cultural diversity particularly in a country like Nigeria are factors that has encouraged intolerance especially over the acceptability or otherwise of sound produced particularly if the sound is associated with a religious practice that is not widely practiced. It is worthy of note that where objections are raised to sounds that are integral to the faiths of a religion whether in the majority or minority, there would be a legitimate concern about whether such opposition is a subterfuge for discrimination. This makes discussions on sounds produced when manifesting a religious belief a sensitive topic with a possible underlying tension that requires being handled with care.

The move towards modernity notwithstanding, the importance of sound to humanity can neither be overlooked nor limited to the extent of totally removing it from the sphere of human life. Sounds made through the manifestation of a religious belief either in praises, songs and preaching are essential part of making sounds. Therefore any restriction however minute on how a religious belief should be manifested, may inevitably distort human life.

This further reiterates the fact that there is a connection between sound, religion and life as captured in Part IV of the Constitution. According to the UN Special Rapporteur 'freedom of religion and belief is not black and white, it deals with people and faith. It is in the emotional realm rather than cut and dry rules and regulations'

Owing to the connection between all the recognized fundamental rights and the fact that none can be asserted in isolation, any restriction to the application of any of the rights will inevitably affect other rights.

Based on the foregoing, this paper considers noise as a social and health problem in the first part while the second part discusses the legal framework of noise pollution in Nigeria. In discussing noise pollution, the third part analyzed the difference between noise and sound, particularly religious sounds. The fourth part considered town planning as a catalyst for environmental noise pollution in Nigeria. Fundamental Human Right in Nigeria, 
with particular focus on the Freedom of thought, conscience and religion would be discussed in the fifth part due to the effect of the Law on noise pollution, on the express manifestation of the right to religion guaranteed in the 1999 Constitution.

The sixth part considers the restrictions to religious rights under the Constitution coupled with those provided in NESRA, with the intent of exposing the conflict that abound within these laws especially when the law seems to recognize this right and grants the citizens the right to assert it on one hand while restricting the exercise of same right on the other hand. The seventh part considers ways of resolving the conflict between law, noise pollution and religious rights by proffering solutions in form of recommendations. A summary of the findings of the paper is made in the conclusion.

\subsection{Conceptual Clarification}

This section defines some of the concepts used in this article for ease of understanding of in the rest of the article. Human right- Human rights are rights inherent to all human beings, regardless of race, sex, nationality, ethnicity, language, religion, or any other status. Human rights include the right to life and liberty, freedom from slavery and torture, freedom of opinion and expression, the right to work and education, and many more. Everyone is entitled to these rights, without discrimination.

Religion- Religions are shared collections of transcendental beliefs that have been passed on from believers to converts, that are held by adherents to be actively meaningful and serious and either based on (1) formally documented doctrine (organized religion) or (2) established cultural practices (folk religion). In both forms, there are religious professionals who embody formal aspects of the religion and who act in positions of leadership and governance with certain rituals reserved for believers belonging to this religion to carry out. The beliefs generate practical implications of how life should be lived.

Pollution- it is man-made or main-aided alteration or chemical, physical or biological quality of the environment beyond acceptable limits and pollutants shall be construed accordingly. Pollution is also any introduction by man, directly or indirectly, of substances or energy into the environment resulting in deleterious effects of such a nature as to endanger human health, harm living resources, ecosystems and material property and impair amenities or interfere with other legitimate uses of the environment.

Noise pollution- It is an environmental pollution. According to Fieid noise pollution is an unwanted excessive harmonious sound that has undesired physiological and institutional effects on individuals. Noise can also be defined as a number of tonal components disagreeable to man and more or less intolerable to him because of the discomfort, fatigue, disturbances and, in some cases, pain it causes.

\subsection{Noise as a Social and Health Problem.}

Noise has been considered an unwelcomed sound which can either be a mild irritation or in extreme cases a major health concern. Noise is not inherently harmful to the human or environment, it can however become dangerous when it is unusually loud and uncontrolled, that it diminishes the quality of air and adversely affects the environment, public health and welfare in general. The excessiveness associated with noise makes it an environmental pollution. The 'perceived' hazardous effects of noise on both human and the climate necessitated the introduction of policies and laws to regulate the level of noise.

Daily, Nigerians especially those in the big cities of the urban area are exposed to different types of sound ranging from horn blaring, siren of police cars, ambulances, music from commercial loudspeakers to car alarms. Experts opine that noise from these sources is a silent environmental pollution which may have negative impact on the health of the recipients.

\section{Legal Framework of Environmental Noise Pollution in Nigeria}

The problem of environmental pollution particularly noise pollution in Nigeria can be considered under two heading which is the common law and the policy/statutes.

\section{A. Common Law}

From the common law perspective, noise pollution can be curbed through the actionable tort of nuisance. Nuisance which can be either public or private, literally means annoyance and may be described as a wrong done to one by unlawfully disturbing him in the enjoyment of his property or in the exercise of a common right. The question as to the amount of annoyance or inconvenience, that will then constitute a nuisance is dependent on the degree of the injury inflicted which must be real and substantial and in the case of private nuisance must be such as to interfere materially with ordinary physical comfort or the reasonable use of property.

Noise would be considered a nuisance to which an aggrieved person can seek damages for injuries directly linked to the offensive noise suffered by the victim, where the noise has caused direct discomfort to the ordinary enjoyment of the plaintiff's property or common law right.

In Tebite v. Marine and trading Co. Ltd (1971) I UILR 432, damages were awarded in favor of the plaintiff, against the defendant who occupied adjoining premises where they carried out the business of boat building and 
repairing. The plaintiff contended that by operating its machines continuously for several hours a day the defendants had persistently caused the emission of loud and excessive noise and noxious fumes from their premises which caused the plaintiff much discomfort and inconvenience. It was established in the course of the proceedings that the noise generated and emitted by the defendants was excessive and much more than any noise that can be produced in any noisy area in Nigeria.

An aggrieved party can also seek an injunction to stop the perpetuator from further emission of such noise as a result of its negative effect on the health of the recipient(s) (see Vandepant v. Mayfair Hotel Co. Ltd (1930) 1 Ch. 138). . The court in Moore v. Nnado (1967) FNLR 156, granted an injunction to the plaintiff against the defendant who was found to be guilty of emitting excessive sound to his neighbors by playing loud music every night. In another case, the court upon receiving evidence of nuisance caused by the defendant through the emission of noise, awarded damages in favour of the plaintiff and further granted injunction against the defendant by the court.

Despite the remedy available under common law, the nuisance of noise pollution continues to increase due to some socio-economic factors such as the cost of legal fees and slow adversarial justice system in Nigeria. Also due to belief that legal battles promotes enmity, Nigerians generally shy away from legal confrontations with neighbors and would rather endure whatever discomfort such nuisance may bring.

This reality informed the introduction of policies by the government to tackle noise pollution. It is worth noting that, in spite of the general belief of people about legal proceedings and the delay in settlement of dispute in court, a victim of noise pollution can still proceed to court to obtain remedy.

B. Statutes and Policies

\section{i. Federal Environmental Protection Agency (FEPA) Act 1989}

The regulation of environmental pollution started with the enactment of the 1988 Federal Environmental Protection Agency (FEPA) Act, this act incorporated most of the policy and commitments of the government on environmental management contained in the1989 National Policy of Environment (NPE). One of the policy goals of the NPE is 'the reduction of noise levels and the control of noise pollution for the creation and maintenance of a comfortable and healthy living environment'. To achieve this, the policy further prescribes the need for guidelines to control the noise level especially those emanating from religious buildings and activities.

The agency created by the FEPA is saddled with the responsibility of consulting with appropriate authority in identifying the major sources of noise, establish noise abatement programs and any necessary noise emission standards to preserve and maintain public health or welfare.

ii. The National Environmental Standards and Regulations Enforcement Agency (NESREA) Act 2007

Due to the shortcomings in FEPA, the 2007 National Environmental Standards and Regulations Enforcement Agency (NESREA) Act was enacted. An in-depth study of the 2007 NESREA Act showed that the provisions of the Act with respect to noise pollution though similar to those contained in the FEPA Act, have certain differences. In contrast to FEPA Act, NESREA Act provided that the agency "make regulations on noise, emission control, abatement as may be necessary to preserve and maintain public health and welfare.

A further deviation from FEPA act is the provision which directed that the agency should mandatorily enforce compliance with existing regulations and recommend programs to control noise originating from industrial, commercial, domestic, sports, recreational, transportation or other similar activities. NESREA Act also recognizes different areas in which noise may be generated as a measure for setting different noise level for the diverse industries existing in Nigeria.

In the exercise of the power conferred on it by the Act, the National Environmental Standards (Noise Standards and Control) Regulations 2009 was introduced with the objective of ensuring a healthy environment for all persons in Nigeria by prescribing and regulating the permissible noise level of a facility or activity people may be exposed to. The agency also provides measures for reducing noise that is above the permissible level.

\section{Noise and Sounds Differentiated.}

That being said, at this juncture it is imperative to distinguish between the different types of sounds, bearing in mind that not all sounds produced lead to noise and inevitably noise pollution. Noise consists of sound, which is transported by air. It is an unwanted sound, irregular and considered unpleasant to the ear. Sounds on the other hand particularly those emanating from music or made in the expression of a religious belief are generally regular and also pleasing to the ears and mind. It should be noted also that the acceptability or otherwise of any sound depends on the listener, the time such sound was made and the circumstances.

Religious noise are religiously motivated sound embraced by the devotees of such religion and emanating from a fixed geographical locations such as churches and Mosques. The Constitution further prohibits religious discrimination with protection targeted to those in the religious minority.

Furthermore, it is worthy of note that the classification of any type of sound as noise pollution is subject to the hearer or recipients of such sound. The challenge then is that there would be conflicting views as to what sort of sound should be classified as noise when made, particularly sounds from religious activities or building. Also 
sounds associated with religious activities are generally pleasing sounds and not conglomeration of noisy sound considered an environmental pollutant. This in essence means that the yardstick for determining the permissible decibel for sounds emanating from religious activities or buildings at the time of enactment of the law may have been subjective in nature.

Also the congenial nature of religious sound would make any restriction on the level of sound produced during the manifestation of a religious belief particularly those from religious buildings a discrimination on grounds of religious as well as an affront not only to their 'God' but also on the participant's right to religion and expression, particularly when the maximum permissible level for noise emanating from other sources which is recurrent seems higher than those provided for places of worship or religious buildings that is intermittent. This further questions the rationale of regulating religious sounds which is intermittent whilst noise from other sources are made daily irrespective of the time.

\section{Noise Pollution and Nigerian Town Planning.}

One of the most notable features of many Nigerian cities is the very disorderly nature of the cities. Many buildings have been and are being constructed without approved layouts or proper spacing. Many illegal structures spring up arbitrarily without it being properly situated i.e constructing residential buildings in commercial areas and vice visa. Most houses constructed in Nigeria do not undergo environmental assessment before they are erected as such the necessary precautions in either ensuring the facility is sound proofed against noise or entirely discontinued if necessary are not done. Over the years, failure of the appropriate authority to take necessary precautions and also ensure compliance with the prescribed rules has resulted in the construction of houses in illegal, inappropriate sites or zone.

Clustered houses with little or no ventilation is another consequence of improper urban planning/zoning which encouraged noise pollution and also made sounds that are not necessarily loud become a pollution due to the close proximity of buildings. In Lagos for instance, it is a norm to find religious buildings and residential houses alongside each other, while some sites are used for purposes incompatible to the land use. Hardly can we find cities in Nigeria complying with the zoning regulations or urban development policy. All these are responsible for high noise exposure levels.

With the present anomaly of town planning particularly in urban areas, it will be foolhardy to expect sounds made in a building that is improperly situated and in close proximity with other buildings not to be regarded as noise by other land users even if made within the decibel level prescribed.

Flowing from the absence of proper planning, religious sounds emanating from a building in the exercise of the public right to religion may be considered noise due to the close proximity of the building to other land users and considered a nuisance. In New Imperial and Windsor Hotel Co. v. Johnson (1912) I Ir. R. 327, 336, the court stated that if a noise does not cause substantial discomfort, residents particularly in large industrial cities may have to put with a certain amount of noise which is incidental to having a crowded population. In the same vein residents in a mixed residence may because of close proximity of buildings have to endure some form of sound made by an assemblage of people exercising their human rights.

\subsection{Fundamental Human Rights in Nigeria.}

Human rights are considered an inalienable right recognized by various international instruments and included in the 1999 Nigerian Constitution as rights very person is entitled to. They are entitlements bestowed on every citizen by the Constitution to be enjoyed without fear of interference. They are rights protected by a legal instrument and given to men to maintain peace and orderliness in a complex society. These rights ensure a continuous happy coexistence of persons in a particular society.

In Nigeria, citizens enjoy many rights but the inalienable fundamental rights of citizens are statute-protected by the amended 1999 Constitution of the Federal Republic of Nigeria. Chapter IV of the Constitution lists out the basic Fundamental Human Rights enjoyed by citizens of the country. These are protected rights are duplicates of the Universal Declaration of Human Right and they are stated under Chapter IV of the Constitution. Even though this paper will focus mainly on section 38 and 45 , it is however essential to list the rights stated in Chapter IV because of these rights are intertwined and never asserted in isolation. The rights include;

i) Right to life, the constitution however provides an exception to the right in cases where the taking of life is in execution of a sentence of a court in respect of a criminal offence in which the person has been found guilty in Nigeria or where the loss of life is as a result of the use of such force as is reasonably necessary and, in such circumstances, as permitted by law;

ii) Right to dignity of human person which requires that no person must be subjected to inhuman or degrading treatment;

iii) Right to personal liberty which includes right not to be imprisoned except in special circumstances and in accordance with a procedure permitted by law;

iv) Right to fair hearing. This right recognizes situations where person is arrested and may need to be arraigned 
before a court or tribunal, this section therefore provides that such persons must have a fair hearing within a reasonable period by a court;

v) Right of citizens to their privacy;

vi) Freedom of thought, conscience and religion. This right also includes the right to change his religion or belief, and freedom (either alone or in community with others, and in public or in private) to manifest and propagate his religion or belief in worship, teaching, practice and observance;

vii) Freedom of expression. This right includes freedom to hold opinions and to receive and impart ideas and information without interference;

viii) Right of assemble and association;

ix) Right of movement throughout Nigeria and residence;

$\mathrm{x}$ ) Right not to be subjected to any form of discrimination, disability or deprivation by reason of to his/her community, ethnic group, place of origin, circumstances of birth, sex, religion or political opinion;

xi) Right to acquire and own immovable property anywhere in Nigeria.

\subsection{Freedom of Thought, Conscience and Religion}

Undoubtedly religion plays a major role at both the international and local level of many countries including Nigeria. This informed the recognition of the religious freedom and the right of expression as a fundamental right in various international instruments as well as the Nigerian Constitution. Section 38 allows each individual to express their thoughts whether religious or otherwise. In asserting this freedom of expression, an individual is expressing his thoughts concerning any issue that is directly linked to his/her conscience which may include religious thoughts.

Aside recognizing human beings as people of conscience with independent minds and thoughts, section 38 further recognizes people's religious freedom without discrimination either through the introduction of a law limiting the expression this right expressly or impliedly or hostility on the part of a predominant religious community where such religion is either unpopular or practiced by few minority group.

In exercising this right, any person can manifest their belief especially for those of the Christian and Islamic faith, through various practices integral to such acts like building places of worship, freedom of followers to express themselves through songs, making joyful noise and praying without ceasing as required in the bible, choosing religious leaders, priests and teachers, the freedom to prepare and distribute religious texts or publications etc.

In manifesting a religious belief, the freedom of peaceful assembly and association would also be deployed irrespective of the religion. The constitution further allows individuals to propagate their belief either alone or in community with others, and in public or in private capacity, this however precludes coercing or compelling people to join a faith by withdrawing other rights or benefits.

In the case of Kokkinakis v. Greece (1993) ECHR 20, the European Court of Human Rights established the importance of the "freedom of thought, conscience and religion" by stating that it is one of the foundations of a democratic society within the meaning of the Convention. It is, in its religious dimension, one of the most vital elements that make up the identity of believers.

Other rights which reinforce section 38 include the right of movement which is relied on mostly by people of the Christian faith to manifest and propagate their religious belief protected by section 41 . Because these rights are interrelated, a restriction on one will automatically affect other rights as none can be fully enjoyed without the others. Any purported regulation of these rights goes against the human right principle of indivisibility.

From the foregoing it is clear the restriction on the level of sound allowed in places of worship will not only affect the full expression of their religious freedom but other rights seeing that none of the fundamental right can be exercised in isolation of other rights.

\section{Restrictions to Religious rights, Noise Pollution and the Conflict of Laws}

Even though the right to freedom of religion as contained in section 38 is not absolute, the derogations allowed has to be under a law that is reasonably justifiable in a democratic society The restriction was considered in the case of Medical and Dental Practitioners Disciplinary Tribunal v Okonkwo ((2001) FWLR (Pt 44) 542) where Ayoola JSC stated that;

'the right to freedom of thought, conscience or religion implies a right not to be prevented without lawful justification from choosing the course of one's life, fashioned on what one believes, and the right not to be coerced into acting contrary to one's belief. The limits of these freedoms, as in all cases, are where they impinge on the rights of others or where they put the welfare of society or public health in jeopardy ... Law's role is to ensure the fullness of liberty when there is no danger to public interest. Ensuring liberty of conscience and freedom of religion is an important component. The courts are the institutions society has 
agreed to invest with the responsibility of balancing conflicting interests in a way to ensure the fullness of liberty without destroying the existence and stability of society'

Flowing from the above statement, there is no basis for restricting a right without lawful justification. It can therefore be surmised that restricting religious right on the premise of welfare of society or public health particularly when there is no established proof of any adverse effect of noise pollution on the health of people in Nigeria is unfair., In the absence of any adverse effect of noise pollution on the health of Nigerians this paper opine that limitation to section 38 on the premise of public health necessitating a further restriction on the level of acceptable sound is highly unnecessary. This restriction can be analyzed from the proverbial angle of bequeathing a gift with one hand and taking it back with the other or restricting the usage of such gift, which is tantamount to not giving the gift.

From the foregoing it is evident that the law recognizes the freedom of religion, however the restriction in section 45 further reiterated by NESREA is clearing a case of taking the right back because religious noise is part of the manifestation of such right. The issue is further complicated in the face of improper urban planning that seem to exaggerate sounds made even when it is low.

Also the intangible nature of noise brings to the fore the issue of the 'perceived' or 'presumed' negative impact of freedom of thought, conscience and religion on other rights, considering there are a number of rights reinforcing section 38 .

The principle of indivisibility of rights has shown that these rights are connected and also reinforce one another, it therefore means that where one right is limited other rights would be affected, especially when it is clear that religious expression without bound is life itself.

Furthermore there is no evidence or study to show that there would or has been actual loss of life and privacy by virtue of the 'sound' generated from manifesting a religion. Without concrete evidence of the adverse effect of religious sound on Nigerian citizen, any purported limitation on the basis of the need to protect the rights of others would be considered discrimination on grounds of religion as well as an infringement of the freedom of religion and other rights.

One of the arguments that continues to resonate is the fact that the limitation prescribed in section 45(1) is in itself an infringement on the absolute freedom of thought, conscience and religion, since acts of worship and others actions done in propagating a belief is an assertion of the right to religion. As such any law seeking to curb the way people express themselves through their religion is an aberration.

Also it should be noted that despite the prescribed level of noise, some individuals due to their peculiar nature may still find the level of sound too high despite compliance with the prescribed level. Consideration should also be given to the absence of proper town planning, environmental assessments and the close proximity of houses. This shows that the acceptable level of sound and what is considered noise is subjective in nature. Also note that noise generated at night even if within the accepted level may resonate louder than usual at night because it is quiet.

Although no religion is adopted as State religion in Nigeria as provided in section 10 of the 1999 amended Constitution, however the government's act of promoting and sponsoring both religions for pilgrims shows the importance attached to religion in Nigeria. The penchant for religion in Nigeria thus queries the limitation to freedom of religion on grounds of public interest and morality, particularly when it is in the public interest that religion is promoted and encouraged. It is note-worthy that religion not only enhances morality, it can also not be divorced from humanity.

Generally it is believed that what is considered noise from church buildings are songs, hymns and prayers enhanced through the aid of amplifiers which is in no way a disturbance and should not be classified as noise. According to renowned preacher Prophet Samuel Kayode Abiara, former General Evangelist, Christ Apostolic Church, CAC, Worldwide 'if the songs, hymns and prayers from churches are seen as disturbance, then the person complaining must have an evil spirit worrying him or her'. All these activities are an expression of the people's freedom of religion particularly for Christians and if such activities are restricted, the essence of the Christian faith is defeated since the hallmark of the Christian religion is these activities, which is also an act of obedience to God's instruction. (see Psalms 98:4, 95:1, 81, 100, Isaiah 44:23. King James Version of the bible)

\section{Resolving the Conflict between the Law, Noise Pollution and Religious Rights}

From the foregoing it is clear that there is an internal conflict between the provisions of the Constitution as well as the law on noise pollution which is needs to be balanced. On one hand the law guarantees the right to religion while restricting the expression of such religion on the other hand on grounds of public interest, order, public health and the need to protect the rights of others. In including these restrictions, the law has failed to comprehend the fact that there a number of other recognized rights which reinforce the enjoyment of this freedom of religion. In order to resolve this conflict, there is need to balance the interests of all parties concerned. To this end, the following is recommended; 
a. There is need to exempt religious sound from the category of sounds subject to regulation and in ensuring these religious sounds do not interrupt the lives of others, religious buildings should not be erected in residential areas as it is presently especially in cities like Lagos, neither should residential buildings be converted for religious purposes like church or mosques.

b. To avoid unauthorized conversions of buildings and ensure strict compliance, there is need for the intervention of urban and town planning agency to check mate arbitral building of private and public buildings to avoid conflict of interest.

c. With proper planning, churches and mosque with their faithful would be able to express themselves to the satisfaction of their 'God' while the general public would in turn have a peaceful life devoid of nuisance like noise pollution. It should be noted that where religious buildings and residential houses are close together in a particular area, it would be difficult to determine which of these noise levels exceed the other. The permissible noise levels provided under the regulation can be enforced only if religious buildings are erected in residential areas.

d. Where religious buildings are erected in residential areas, churches must mandatorily soundproof their building to forestall noise proliferation. This measure would also help in resolving the conflict between the need for the law to take its course and the rights enshrined in the law.

e. The law should also prohibit building of religious houses in areas where 24-hour average noise levels exceed 50dB similar to Netherland Law.

f. Enforcement has always clogged the effective implementation of any enacted law in Nigeria including NESRA, as such there is need to beef up the enforcement mechanisms including the agency. The Lagos Government is one of the states at the fore front in the fight against noise pollution. In ensuring all interests are balanced, LASEPA an agency created by the government is empowered to enforce prescribed sanctions, this informed the initial warning given to some churches and eventual closure for failure to comply with the terms in the warning notice.

g. In the face of this conflict, noise pollution should be restricted to the common law doctrine of nuisance instead of having other laws that seems to 'takeaway' people's freedom to manifest their religious rights. Victims of such nuisance should be encouraged to pursue remedies available under common law to remedy the situation which would serve as deterrence for others.

\section{Conclusion}

This paper has discussed the effect of manifesting section 38 of the 1999 Nigerian Constitution amended particularly freedom of religion on Nigerians and the fact that other secondary rights aid the reinforcement of this right, thus showing the interconnectivity of all rights recognized in Part IV of the Constitution. Therefore the restriction on section 38 is an implied restriction on other rights, especially when it has been identified that religion play a pivotal role in the implementation of any public policy, even though Nigeria does not have any adopted religion as a state religion. The act of inserting a caveat, can be likened to giving a gift with one hand (allowing people have a freedom of religion) and taking it back with the other (restricting the expression of such religion which is tantamount to not having right to religion)

This raises the question of how to juxtapose the conflict between the law on one hand with the freedom of thought, conscience and religion, having identified that present town planning in Nigeria particularly in urban cities amplify sounds created by religious bodies (Christians and Muslims) whilst manifesting and propagating their religion under section 38 even when it's not above the prescribed decibel.

In order to resolve this conflict and balance the interest of all parties, this paper identifies the need for concerted efforts of all Nigerians, particularly the enforcement agency to increase their level of enforcement i.e town planning agencies.

\section{References}

1. Adebayo R., (2013) 'Abuse of Religion and Environmental Pollution' Vol. 21, No. 1, International Discourse National Policy of Environment, <http://www.nesrea.gov.ng/wp-content/uploads/2017/09/National-Policyon-Environment.pdf>.

2. Ahamed

'UN:

UN Rapporteur on Religious Freedom or Belief" Women Living Under Muslim Laws.

3. Akinpelu A., (2014) 'Perceived Effect of Noise Generated by Religious Houses on the Health of People of Osun State, Nigeria' Vol.5, No.19, Journal of Education and Practice 91, 93.

4. Aluko O E., (2011) 'Urbanization and Effective Town Planning in Nigeria' Vol. 5(2), No. 9, African Research Review.

5. Crabtree V., 'What is Religion? How do you define Religion?'< http://www.humanreligions.info/what_is_religion.html>

6. Ekpendu I. C., Audu D. S. and Ekpendu C. I., (2016) 'An evaluation of the role of Religion in the 
Development of Nigeria', Vol. 6 No 10, Developing Country Studies 82.

7. Ezeanokwasa J., (2016) 'Religious Freedom and Its Limitations under the 1999 Constitution of Nigeria' NAUJILI 57.

8. Fadairo G., 'Urban Centres Noise Pollution: Case Study of Akure, Nigeria', (2013), Vol.14 No II, British Journal of Arts and Social Sciences.

9. Fieid J.M., (1993) 'Effects of Personal and Situational Variables Upon Noise Annoyance in Residential Areas', Journal of the Acoustical Society of America 93.

10. Garrioch D., (2003) Sounds of the City: the Soundscape of early modern European Towns, Urban History, Cambridge University Press.

11. Hamza, (2008) 'Noise Pollution Regulatory Measures for Protection of Ecosystem', Faculty of Law Journal, 2007-2008.

12. Killen C., (1998) 'Loneliness: an epidemic in Modern Society', 28(4) Journal of Advanced Nursing, 762.

13. Lee N., 'Noise Pollution is a bigger threat to your health than you may think and Americans aren't taking it seriously', <http:/www.pulse.ng/bi/tech/tech-noise-pollution-is-a-bigger-threat-to-your-health-than-youmay-think-and americans-arent-taking-it-seriously-id7899548.html>.

14. Lloyds W., (1934) 'Noise as a Nuisance', University of Pennsylvania Law Review and American Law

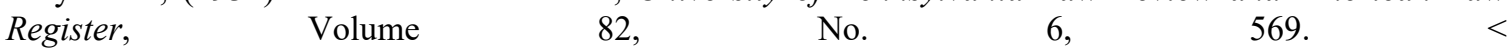
https://scholarship.law.upenn.edu/cgi/viewcontent.cgi?referer=https://www.google.com.ng/\&httpsredir=1\& article $=8661 \&$ context $=$ penn_law_review $>$

15. Murphy E. and Eoin A. K., (2014) Environmental Noise Pollution: Noise Mapping, Public health and Policy, $1^{\text {st }}$ edition Elsevier.

16. Nwauche E., (2008) 'Law, religion and human rights in Nigeria' 8 African Human Rights Law Journal.

17. Odunsi, S. B. and Ogunleye, T. A., (2007) 'Noise Pollution and Environment: The Nigerian Perspective' 5th International Conference on International Environmental Law, New Delhi, December.

18. Okorodudu-Fubara, M. T., (1998) Law of Environmental Protection Materials and Text, Caltop Publication Ltd.

19. Olofinji L., 'Nigerian Religious Centres and their Neighbors' Nigeria Real Estate Hub (16 April, 2015) $<\mathrm{http}: / /$ nigeriarealestatehub.com/nigerian-religious-centres-and-their-neighbours-part-2.html/>

20. Oyedepo S, (2013) 'Effective Noise Control Measures and Sustainable Development in Nigeria', Vol. 1, No. 1, World Journal of Environmental Engineering.

21. Seema P. S., (2003) 'Noise Pollution - Human Rights and Constitutional Dimensions' 80 Cochin University Law Review.

22. United Nations, 'Human Right' <http://www.un.org/en/sections/issues-depth/human-rights/>

23. W. H O, (1999) 'Guidelines for Community Noise in WHO Expert Task Force Meeting held in London in April.

24. Sections 33- 46 of the Constitution of the Federal Republic of Nigeria 1999 Cap. C23 L.F.N. 2004

Newspapers

a. Adedeji, A. "How Noise Fumes from Generators are Killing Nigerians," The Punch Newspaper, (May 16, 2005) p. 40

b. Irekamba C., 'Why Lagos Government Finds It Difficult to Handle Noise Pollution', The Guardian Newspaper (Nigeria, 7 January, 2018)

c. Daily Trust, 'New National Policy on Environment' Daily Trust (24 Feb, 2017)

d. Editorial, 'Dapchi Girls Saga; An unfinished Business' Vanguard (Nigeria, 28 March, 2018)

e. Food Security Cluster, 'Internal Displacement In North East Nigeria: Operationalising The Kampala Convention In Borno, Adamawa And Yobe States', February 7, pg 129-130.

f. Gbadamosi, G. "Wanted: New Legal Regime to Confront Noise Pollution," The Punch Newspaper, $\left(11^{\text {th }}\right.$ May 2009), p.40

g. Fulani I. R., 'Four Years After, Chibok Parents Grieve' Premium Times (16 April 2018).

h. Bering J., 'We are programmed to believe in a god' The Guardian Newspaper (4 Jan 2011).

i. $\quad$ Nwachukwu J., 'Boko Haram Hits IDP camp In Borno, Many Feared Dead', Premium Times, (Nigeria, 31 January, 2018)

j. $\quad$ Yacob A., 'Urban Planning in Nigeria: Advocacy for Change', Environ News (Nigeria, 2014). 